\title{
EFISIENSI PENGGUNAAN INPUT USAHATANI BAWANG PUTIH LOKAL EBANDI MIOMAFFO BARAT KABUPATEN TIMOR TENGAH UTARA
}

\author{
Efficient Use Farm Input Of Eabn Local Garlic \\ In Western Miomaffo Timor Tengah Utara District
}

\author{
Simon Juan Kune, Adeline Norawati Hutapea
}

Program Studi Agribisnis Fakultas Pertanian, Universitas Timor, Nusa Tenggara Timur, Indonesia

Email:simonjuankune@gmail.com

\begin{abstract}
The purpose of this research is to know the description of farming system and to analyze the technical and allocative efficiency of Eban local garlic farming by using survey method while the data used are primary and secondary data. Data analysis using descriptive analysis and stockhastic frontier analysis. The results of the general overview of Eban's local garlic farms include; land preparation, seed preparation, planting, maintenance and harvesting. While technically Eban local garlic farming is efficient where the analysis conducted for 50 respondents shows the efficient average achieved by $92 \%$ while the allocation of local garlic farming has not been efficient because of the calculation of $N P M x / p x>1$.
\end{abstract}

Keywords: Technical efficiency, allocative efficiency, Eban garlic farming

\begin{abstract}
Abstrak
Penelitian ini bertujuan untuk mengetahui gambaran usahatani dan menganalisis efisiensi teknis dan alokatif usahatani bawang putih lokal Eban dengan menggunakan metode survei sedangkan data yang digunakan adalah data primer dan sekunder. Analisa data menggunakan analisis desriptif dan analisis stokhastic frontier. Hasil penelitian menunjukkan bahwa usahatani bawang putih lokal Eban meliputi; persiapan lahan, persiapan bibit, penanaman, pemeliharaan dan panen. Sementara secara teknis usahatani bawang putih lokal Eban sudah efisien dimana analisis yang dilakukan untuk 50 responden menunjukan rata-rata efisien yang dicapai sebesar $92 \%$ sementara secara alokatif usahatani bawang putih lokal belum efisien karena hasil perhitungan $\mathrm{NPMx} / \mathrm{px}>1$.
\end{abstract}

Kata Kunci : Efisiensi teknis, efisiensi alokatif, usahatani bawang putih Eban

\section{PENDAHULUAN}

\section{Latar Belakang}

Bawang putih lokal Eban merupakan tanaman hortikultura yang multi fungsi baik sebagai penyedap rasa maupun sebagai bahan obat. Bawang putih lokal Eban telah dibudidayakan secara turun temurun dan juga sebagai komoditi lokal unggulan di Kabupaten Timor Tengah Utara.

Usahatani bawang putih lokal Eban terus dilakukan oleh masyarakat setiap tahun walau dalam jumlah yang terbatas, pemerintah melalui dinas teknis terkait terus berupaya untuk tetap mengusahakan tanaman bawang putih sebagai salah satu produk unggul lokal daerah ini. Daerah dengan kondisi iklim dan lingkungan yang cocok dan berpotensi adalah kecamatan Miomaffo Barat, karena daerah ini memiliki spesifikasi yang cocok untuk pertumbuhan tanaman bawang putih (ketinggian $700-1100 \mathrm{M} \mathrm{dpl}$ (diatas permukaan laut) dengan suhu rata-rata $20^{\circ}-$ $25^{\circ} \mathrm{C}$ dan memiliki curah hujan rata-rata $1200-2400$ $\mathrm{mm}$ per tahun serta menghendaki tekstur tanah yang gembur dan subur) dan juga bagi masyarakatnya usahatani bawang putih telah dilakukan secara turuntemurun.

Pada tahun 2011 produksi bawang putih di Desa Fatuneno dan Desa Noepesu sebesar 13 Ton dengan luas lahan 118,35 ha, sedangkan pada tahun 2012 produksi bawang putih 16,5 ton dari luas lahan 146,4 ha,tahun 201320 ton dari 157,8 ha, sedangkan pada tahun 2014-2015 produksi bawang putih di Desa 
Fatuneno mengalami penurunan menjadi 10 ton dari luas lahan 35 ha hal ini disebabkan karena iklim pada tahun 2014-2015 tidak stabil.

Berdasarkan data produksi diatas bawang putih lokal Eban belum mampu menjawabi permintaan konsumen. Hal ini berarti produksinya masih perlu untuk ditingkatkan, penyebabnya antara lain curah hujan yang tidak stabil, luasan areal tanam dan luas panen yang semakin sempit oleh pembagian lahan keluarga yang berdampak pada jumlah produksi yang diperoleh, akibatnya untuk memenuhi permintaan konsumen harus import bawang putih dari luar daerah (survei awal). Selain dari pada itu kurang efisiennya penggunaan input seperti lahan, bibit, tenaga kerja, pupuk, obat-obatan dan faktor-faktor sosial seperti umur, pendidikan, pengalaman dan jumlah tanggungan keluarga juga turut mempengaruhi produksi bawang putih lokal Eban.

Berdasarkan gambaran di atas, maka perlu diadakan penelitian untuk menjawab permasalahan di atas dengan judul "Efisiensi Penggunaan Input Bawang Putih Lokal Eban di Fatu Neno"

\section{Perumusan Masalah}

Berdasarkan latar belakang penelitian, maka dirumuskan pokok-pokok masalah sebagai berikut :

1. Bagaimana gambaran usahatani bawang putih lokal Eban?

2. Apakah usahatani bawang putih lokal Eban sudah mencapai tingkat efisiensi secara teknis dan alokatif ?

\section{Tujuan Penelitian}

Berdasarkan permasalahan dalam penelitian ini maka tujuan dari penelitian ini antara lain untuk :

1. Mengetahui gambaran usahatani bawang putih lokal Eban

2. Menganalisisefisiensi teknis dan alokatif usahatani bawang putih lokal Eban.

\section{METODOLOGI PENELITIAN}

\section{Kerangka Pemikiran}

Usahatani bawang putih lokal eban yang telah dilakukan petani secara turun temurun, dengan menggunakan factor-faktor produksi seperti lahan, bibit, tenaga kerja, pengalaman, pendidikan dan jumlah tanggungan keluarga. Hingga saat ini masih terus dilakukan dan telah banyak mencuri perhatian berbagai kalangan, baik pemerintah, perguruan tinggi, LSM dan lembaga peneliti, hal ini disebabkan oleh usahatani bawang putih local belum dilakukan secara efisien, baik efisien secara teknis, harga maupun ekonomis.

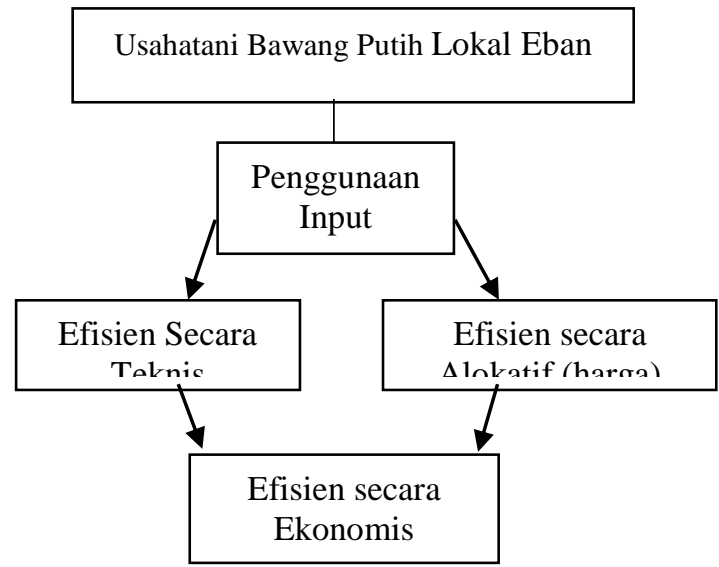

Gambar 3. KerangkaBerpikir

\section{Hipotesis}

Hipotesis yang diangkat dalam penelitian ini adalah: usahatani bawang putih local Eban belum mencapai tingkat efisiensi baik secara teknis maupun secara harga.

\section{Tempat dan waktu penelitian}

Tempat penelitian ditentukan secara purposive, yakni ditentukan oleh peneliti dengan pertimbangan di Desa Noepesu, Fatuneno memiliki luas lahan dan produksi tertinggi di Miomaffo Barat Waktu penelitian mulai bulan Maret hingga Agustus 2017.

\section{Metode Pengumpulan Data dan Jenis Data}

Pengumpulan data penelitian ini menggunakan metode observasi dan wawancara dengan instrumen pengumpulan data berupa kuesioner terstruktur. Data yang digunakan dalam penelitian ini berupa data primer yang diperoleh dari hasil wawancara di lapangan dan data sekunder berupa dokumen publik, surat kabar maupun literatur hasil penelitian yang diperoleh dari instansi pemerintah dan media massa baik cetak maupun elektronik.

\section{Metode Penentuan Populasi dan Sampel}

\section{Populasi}

Populasi dalam penelitian ini patani bawang putih lokal eban di Desa Noepesu dan Desa Fatu Neno.

\section{Sampel}

Sampel dalam penelitian ini dilakukan secara sengaja dengan pertimbangan petani contoh, memiliki luas lahan lebih dari 50 are. Diperoleh 50 0rang responden dari kedua Desa. 


\section{Pengamatan dan Konsep Pengukuran}

Konsep pengukuran penelitian ini adalah;

1. Identitas responden (nama, umur, jeniskelamin, pendidikan, jumlah tanggungan keluarga).

2. Gambaran usahatani bawang putih (persiapan lahan, penanaman, pemeliharaan, pemanenan dan pasca panen).

3. Produksi adalah hasil yang diperoleh petani dalam 1 kali musimtanam (ton/are).

4. Luas lahan adalah luas lahan yang digunakan oleh petani untuk berusahatani bawang putih (are).

5. Benih adalah jumlah benih yang digunakan untuk berusaha tani bawang putih $(\mathrm{kg})$.

6. Tenaga kerja adalah jumlah curahan tenaga kerja yang dibutuhkan dalam usahatani bawang putih (HKO).

7. Pengalaman usahatani adalah lamanya petani melakukan usahatani bawang putih (tahun).

8. Pendidikan petani adalah lamanya pendidikan formal yang dilalui oleh petani (tahun).

9. Jumlah pupuk yang digunakan (kg/musim tanam)

10. Jumlah obat-obatan yang digunakan (liter/ musim tanam)

\section{Metode Analisis Data}

Analisis data penelitian ini menggunakan empat metode yaitu sebagai berikut:

1. Untuk menganalisis tujuan pertama digunakan analisis deskriptif kualitatif.

2. Untuk menganalisis tujuan kedua digunakan analisis Stokhastic Frontier, untuk mengestimasi sejumlah parameter dari fungsi produksi dan biaya yang digunakan dalam sistim usahatani.

$\underset{\mathrm{m}}{\mathrm{Ln}} y_{\mathrm{i}}=\beta_{0}+\sum \beta_{\mathrm{m}} \ln x_{m i}+\mathrm{ei}$

dimana:

$\mathrm{y}=$ output

$\mathrm{x}=$ input (luas lahan, tenaga kerja, bibit, pengalaman, pendidikan, jumlah tanggunan keluarga)

$\beta=$ parameter yang akan diestimasi

$\mathrm{e}_{\mathrm{i}}=$ komponen error

Selanjutnya menjawab tujuan pertama yaitu mengetahui tingkat efisiensi teknis. Tingkat efisiensi teknis dalam usahatani jagung dikategorikan dalam beberapa kelompok yang disebut dengan indeks efisiensi teknis yaitu menggambarkan perbedaan tingkat efisiensi teknis yang dicapai oleh petani jagung yang berbeda-beda. Efisiensi atau inefisiensi teknis usahatani jagung di desa Bitefa diduga dengan menggunakan persamaan matematis sebagai berikut:

$$
T E i=\mathrm{Yi} / \mathrm{Yi}^{*}
$$

dimana :
TEi : Efisiensi Teknis yang dicapai oleh observasi ke- $i$ Yi : Output aktual usahatani jagung $(\mathrm{kg} / \mathrm{ha})$

$\mathrm{Yi}^{*}$ : Output potensial usahatani jagung $(\mathrm{kg} / \mathrm{ha})$

TEi adalah efisiensi teknis petani ke-i, yaitu $0<$ TEi $<$ 1. Nilai efisiensi teknis tersebut berhubungan terbalik dengan nilai efek inefisiensi teknis dan hanya digunakan untuk fungsi yang memiliki jumlah output dan input tertentu (cross section data).

Usahatani bawang putih lokal eban dapat dikatakan efisien apabila nilai produk marginal (NPM) suatu faktor produksi sama dengan harganya. Untuk mengetahui tingkat efisiensi alokatif dari usahatani ditunjukkan dengan nilai rasio NPMxi dengan Pxi dari masing-masing faktor produksi. (Soekartawi 2002).

$$
\begin{aligned}
& E p=\frac{d y / y}{d x / x}=\frac{d y \cdot x}{d x \cdot y} \quad=\frac{P M(\text { Produk Marginal })}{P R(\text { Produk Rata }- \text { rata })}= \\
& \pi=\mathrm{TR}-\mathrm{TC} \\
& \pi \text { max tercapaipada saat } \pi^{\prime}=0
\end{aligned}
$$

$$
\frac{d y \cdot P y}{d x}=\frac{d y \cdot P x}{d x .} \frac{d y \cdot P y}{d x}=P x
$$

MPP.Py $=$ Px

NPMx $=$ Px, Jadi

$$
\frac{N P M x i}{P x i}=1
$$

Dimana :

NPMxi : nilai produk marginal (Rp)

Py : harga produk persatuan $(\mathrm{Rp})$

Epi : elastisitas produk ke- $i$

Y : produksi (kg)

$\mathrm{Xi}$ : faktor produksi ke- $i$

\section{HASIL DAN PEMBAHASAN}

Gambaran umum usahatani bawang putih lokal eban

Kegiatan usahatani bawang putih di Desa Fatuneno dan Desa Noepesu dilakukan dengan beberapa proses yakni: pengolahan lahan, persiapan bibit, penanaman, pemeliharaan, panen, pasca panen dan pemasaran.

a. Pengolahan Lahan

Pengolahan lahan merupakan tahap awal dalam menanam bawang putih. Proses pengolahan ini diawali dengan pembersihan, biasanya dilakukan oleh masing-masing petani pada lahan pertanian mereka sendiri ada yang melakukan dengan sistem gotong royong. Biasanya mereka melakukan pembersihan antara 5-13 hari dengan rata-rata jumlah tenaga kerja antara 2-4 orang.

Dalam pengolahan lahan, masyarakat di Desa Fatuneno dan Desa Noepesu masih menggunakan sistim tradisional karena mereka masih menggunakan system tebas bakar yang merupakan tradisi pengolahan lahan secara turun 
temurun. Alat pertanian yang digunakan dalam proses pengolahan lahan antara lain parang, pacul, linggis, tajak, karung dan sabit.

b. Persiapan bibit

Bibit yang digunakan oleh petani responden bawang putih di Desa Fatuneno dan Desa Noepesu diperoleh dari hasil panen musim tanam sebelumnya dengan cara memilih umbi yang berkulitas, dalam hal ini jika bawang putih tersebut memiliki umbi yang besar dan memiliki siung yang banyak maka diikat lalu diasapi sehingga tahan lama dan tahan akan bakteri penggangguyang dapat mempengaruhi kualitas benih.

c. Penanaman

Penanaman Bawang putih di Desa Fatuneno dan Desa Noepesu sudah diusahakan turun temurun dengan pola penanaman secara tradisional, dimana penanaman bawang putih dilakukan dengan menggunakan tugal dengan jarak tanam tergantung keinginan petani tanpa ada ukuran yang jelas . Penanaman bawang putih di Desa Fatuneno dan Desa Noepesu biasanya dilakukan pada awal bulan Mei dengan tujuan agar bawang putih yang telah ditanam tidak digenangi air hujan dan terhindar dari kabut yang berlebihan karena jika curah hujan tinggi maka bawang putih akan terserang penyakit yang mengakibatkan bercak-bercak putih dan akhirnya mati.

d. Pemeliharaan

Pemliharaan yang dilakukan oleh petani di Desa Fatuneneo dan Desa Noepesu dapat dilihat sebagai berikut:

a. Pemupukan

Sesuai dengan hasil penelitian, bawang putih di wilayah Fatuneno dan wilayah Noepesu tidak diberi pupuk anorganik karena menurut mereka, jika diberi pupuk maka bawang putih yang tumbuh tidak bertahan lama dan terakhir bias mati. Hal ini terjadi karena menurut responden faktor alam sangat mendukung dalam hal ini lahan di wilayah tersebut cocok untuk ditanami bawang putih scara alami tanpa diberi pupuk anorganik. Petani hanya menggunakan pupuk kandang dari masyarakat sekitar, selain itu juga sistem tebas bakar dianggap sebagai pupuk karena mereka beranggapan bahwa sistim itu dapat menyuburkan tanah.

b. Penyiangan

Hasil penelitian menunjukkan bahwa setelah bawang putih yang ditanami tumbuh sekitar 2 minggu, maka selanjutnya petani di Desa Fatuneno dan Desa Noepesu melakukan pemeliharaan dengan cara, membersihkan tumbuhan pengganggu berupa rerumputan dan tunas baru pada pohon-pohon yang dibersihkan sebelumnya. Kegiatan ini dilakukan masingmasing petani pada lahan pertanian mereka sendiri.

e. Panen dan Pasca Panen

Musim panen dan pasca panen bawang putih yang dilakukan oleh petani di Desa Fatuneneo dan Desa Noepesu dapat dilihat sebagai berikut:

a. Panen.

Sesuai hasil penelitian, Bawang putih di Desa Fatuneno dan Desa Noepesu akan dipanen ketika berumur 3 bahkan 3,5 bulan terhitung dari saat penanaman. Ketika sudah tiba waktunya untuk dipanen maka bawang putih di cabut dengan menggunakan tajak lalu dijemur dengan batangnya hingga kering.

b. Pasca panen

Setelah dipanen bawang putih akan dijemur dengan batangnya sampai kering. Proses penjemuran ini dilakukan agar umbi yang baru dipanen mengeras sehingga terhindar dari kebusukan. Setelah dijemur bawang putih dipisahkan dari batangnya lalu dimasukan kedalam karung dan siap untuk dipasarkan. Hasil panen bawang putih tidak seluruhnya dipasarkan tetapi disisihkan sebagian untuk benih pada musim tanam berikutnya sesuai dengan luas lahan yang direncanakan.

c. Pemasaran

Hasil produksi bawang putih dari masing-masing petani berbeda - beda, hal ini terjadi karena luas lahan usahatani bawang putih juga berbedabeda, sehingga berpengaruh pada pendapatan petani juga ikut berbeda. Selain itu juga salah satu faktor yang membedakan pendapatan petani adalah harga yang tidak sama, hal ini terjdi karena belum ada kesamaan harga antara petani yang satu dengan petani yang lainnya.

Sesuai dengan hasil penelitian penulis, bawang putih di Desa Fatuneno dan Desa Noepesu dijual kepada pedagang. Ada yang menjual dirumahnya sendiri ada juga yang menjual di pasar, namun masyarakat di Desa Fatuneno dan Desa Noepesu lebih cenderung menjual bawang putih ke pasar Kefamenanu dengan harga jual berbeda-beda tergantung pada kesepakatan antara penjual dan pembeli. Harga penjualan bawang putih di Desa Fatuneno dan Desa Noepesu berkisar antara Rp. 20.000 sampai Rp.45.000 per kg. 


\section{Analisis Efisiensi Usahatani Bawang Putih Lokal Eban}

\section{Faktor-Faktor yang Berpengaruh Terhadap Produksi Bawang local Eban}

Pendekatan Stochatik Frontier digunakan dalam menganalisa faktor-faktor yang berpengaruh terhadap produksi bawang lokal eban adalah pendekatan Maximum Likelihood Estimattion (MLE), hasil estimasi dapat dilihat pada Tabel 1.

Tabel 1. Hasil Estimasi Parameter Fungsi Produksi Stochastic Frontier Usahatani bawang lokal eban di desa Miomaffo Barat 2017 dengan Pendekatan Maximum Likelihood Estimation (MLE)

\begin{tabular}{|c|c|c|c|}
\hline Variabel & coefisien & $\begin{array}{l}\text { Standar } \\
\text { error }\end{array}$ & t-ratio \\
\hline Intersep & 5.085 & 2.309 & 2.201 \\
\hline Luas lahan (X 1) & 0.443 & 0.467 & 0.947 \\
\hline Benih (X2) & 0.24 & 0.883 & 0.272 \\
\hline TK (X3) & 0.038 & 0.244 & 0.158 \\
\hline alat (X4) & 0.233 & 0.281 & 0.829 \\
\hline Pupuk (X5) & 0.209 & 0.142 & $1.473 * *$ \\
\hline Obat-obatan (X6) & 0.108 & 0.286 & 0.379 \\
\hline sigma-squared & 0.013 & 0.003 & 3.737 \\
\hline Gamma & 0.884 & 0.08 & 11.002 \\
\hline $\begin{array}{l}\text { log likelihood } \\
\text { function }\end{array}$ & \multicolumn{3}{|c|}{59.879} \\
\hline $\begin{array}{l}\text { LR test of the one- } \\
\text { sided error }\end{array}$ & \multicolumn{3}{|c|}{9.235} \\
\hline
\end{tabular}

Sumber : Data Primer Diolah 2017

Keterangan :* signifikan pada $\alpha 20 \%$ (1.298)

Berdasarkan hasil estimasi dengan Pendekatan Maximum Likelihood Estimation (MLE) dengan software frontier 4.1. diketahui bahwa ada variabel yang berpengaruh secara signifikan dan ada yang berpengaruh tapi tidak signifikan.

\section{Pengaruh dari variabel-variabel faktor produksi}

a. Luas Lahan

Berdasarkan Tabel 1. lahan mempunyai koefisien yang positif yakni sebesar 0.443 dengan nilai $t_{\text {hitung }} 0.947$, dengan ini berarti nilai $t_{\text {hitung }}$ lebih kecil dari $t_{\text {tabel }}$ yaitu 1,298. Memiliki nilai koefisien positif berarti variabel luas lahan berpengaruh terhadap produksi bawang lokal eban pada tingkat kesalahan $20 \%$ tetapi tidak nyata, hal ini disebabkan oleh karena lahan yang diusahakan adalah lahan bekas usahatani jagung pada musim sebelumnya.

b. Benih

Nilai koefisien benih bertanda positif yakni sebesar 0.240 dan nilai $t_{\text {hitung }} 0.272$. Nilai $t_{\text {hitung }}$ lebih kecil dari pada $t_{\text {tabel }}$ pada taraf $20 \%(1,298)$, dengan demikian faktor benih berpengaruh terhadap produksi bawang lokal eban di daerah penelitian tetapi tidak nyata. Ini disebabkan oleh karena benih yang digunakan petani di lokasi penelitian bukanlah benih yang memiliki lisensi atau bukanlah benih unggul, benih yang digunakan adalah benih lokal yang sudah lebih dari tiga sampai empat kali turunannya bahkan lebih.

c. Tenaga Kerja

Untuk variabel tenaga kerja nilai koefisiennya bertanda positif sebesar 0.038 dan nilai $t_{\text {hitung }}$ 0.158 . Nilai $t_{\text {hitung }}$ lebih kecil dari pada $t_{\text {tabel }}$ pada taraf $20 \%$ dengan demikian faktor tenaga kerja berpengaruh tidak nyata terhadap produksi bawang lokal eban tidak nyatanya pengaruh variabel tenaga kerja ini disebabkan karena di lokasi penelitian para petani dalam melakukan kegiatan usahataninya masih menggunakan sistem kerja sama dalam keluarga maupun dengan kerabat petani sehingga jumlah tenaga kerja yang semakin tinggi cenderung tidak aktif dalam bekerja.

d. Alat

Untuk variabel biaya nilai koefisiennya bertanda positif yakni sebesar 0.233 dan nilai $t_{\text {hitung }} 0.829$. Nilai $t_{\text {hitung }}$ lebih kecil dari pada $t_{\text {tabel }}$ pada taraf $20 \%$ dengan demikian faktor alat yang digunakan berpengaruh tidak nyata terhadap produksi jagung di daerah penelitian. Berpengaruh tidak nyatanya variabel alat ini disebabkan karena di lokasi penelitian peralatan yang dignakan untuk usahatani tidak menjadi sebuah masalah yang berarti bagi petani karena petani hanya membutuhkan tofa (tugal) untuk membuat lubang tanam yang dapat diganti dengan kayu atau bahkan hanya menggunakan tangan saat membuat lubang tanam.

e. Pupuk Kandang

Untuk variabel pupuk kandang nilai koefisiennya bertanda positif yakni sebesar 0.209 dan nilai $\mathrm{t}_{\text {hitung }}-1.473$. Nilai $\mathrm{t}_{\text {hitung }}$ lebih besar dari pada $\mathrm{t}_{\text {tabel }}$ pada taraf $20 \%(1,298)$. Hal ini berarti variable pupuk kandang berpengaruh nyata terhadap produksi bawang lokal eban, hal ini disebabkan oleh karena di lokasi penelitian bawang ditanam kembali pada lahan yang sebelumnya digunakan untuk menanam jagung dan sudah diberi pupuk kandang sehingga penggunaan pupuk dapat mengembalikan kesuburan tanah.

\section{f. Sigma-Square, Gamma}

Nilai sigma-square $(\sigma)$ dan gamma $(\gamma)$ yang diperoleh dari pendugaan dengan menggunakan metode MLE adalah sebesar 0,013 dan 0.884. Dari hasil penelitian ini nilai $(\sigma)$ yang lebih besar dari nol berarti bahwa terdapat pengaruh technical inefficiency dalam model fungsi produksi. Nilai gamma $(\gamma)$ 0,884 menunjukkan bahwa kesalahan atau error yang disebabkan oleh komponen technical inefficiency yaitu sebesar $88,4 \%$, angka ini berarti bahwa adanya perbedaan antara 
produksi sebenarnya dengan produksi maksimum lebih disebabkan oleh adanya efek inefisiensi teknis, sedangkan sisanya 12,6\% disebabkan oleh variabel kesalahan acak atau variabel diluar dari model yang dibangun seperti cuaca dan serangan hama penyakit.

Uji hipotesa yang dilakukan dalam penelitian ini dengan menggunakan hasil pendugaan Likehood Ratio Test (LR) dengan menggunakan software frontier 4.1. Nilai LR test yang dalam hasil frontier dengan menggunakan metode MLE sebesar 59.88. Hasil nilai LR test kemudian dibandingkan dengan nilai kritis $\chi_{R}^{2}$ (Kodde dan Palm, 1986) dengan jumlah restriction sebanyak 1 dengan tingkat kesalahan $20 \%$ adalah sebesar 9,235. Setelah dibandingkan, didapatkan hasil bahwa nilai LR test lebih besar daripada nilai kritis $\chi_{R}^{2}$. Hal ini menunjukkan koefisien dari masingmasing variabel di dalam model efek inefisiensi memiliki pengaruh terhadap tingkat inefisiensi di dalam proses produksi usahatani bawang lokal eban.

\section{Tingkat Efisiensi Teknis dan Alokatif Usahatani Bawang Lokal Eban}

Analisa tingkat efisensi teknis pada usahatani jagung bertujuan untuk mengetahui tingkat efisiensi tertinggi dan efisiensi terendah serta efisiensi rata-rata yang dicapai oleh petani dalam berusahatani bawang local ebandi Miomaffo Barat. Tingkat efisiensi yang dicapai oleh responden di daerah penelitian berkisar antara $0,84(84 \%)-0,98(98 \%)$ dengan rata-rata efisiensi yang dicapai petani $0,92(92 \%)$.

Berdasarkan data ini berarti bahwa petani masih memiliki kesempatan sebesar $1-8 \%$ untuk meningkatkan produksi bawang lokal eban. Tingkat efisiensi yang berbeda antar petani ini menunjukkan adanya perbedaan penggunaan faktor-faktor produksi tiap petani.

Selain dari itu perbedaan tingkat efisiensi dapat disebabkan oleh faktor tingkat umur petani, pengalaman usahatani, pendidikan formal, pendidikan nonformal dan juga jumlah anggota keluarga. Petani di daerah penelitian rata-rata tingkat efisiensi teknisnya belum sampai satu. Hal ini menunjukkan bahwa petani jagung di daerah penelitian masih ada kesempatan untuk meningkatkan efisiensi teknis atau produksi aktual yang belum mendekati produksi potensial. Tingkat efisiensi dapat dilihat pada Tabel 2.

Tabel 2. Distribusi Statistik Efisiensi Teknis Usahatani Bawang Lokal Eban 2017

\begin{tabular}{clc}
\hline No & Statistik & Tingkat Efisiensi \\
\hline 1 & Minimum & 0,84 \\
2 & Maksimum & 0,98 \\
3 & Rata-rata & 0,92 \\
\hline
\end{tabular}

Sumber : Data Primer Diolah 2017

Berdasarkan data Tabel 2. terlihat bahwa tingkat efisiensi teknis usahatani bawang terendah yaitu sebesar 0,84 artinya bahwa petani pada tingkat efisiensi ini mampu mencapai $84 \%$ dan masih ada peluang sebesar $16 \%$ bagi petani untuk dapat meningkatkan produksi usahatani bawang dengan penggunaan faktor-faktor produksi yang lebih efisien. Sementara tingkat efisiensi tertinggi yaitu sebesar 0,98. Ini juga berarti bahwa petani sudah mencapai 98\% dari potensial produksi bawang yang diperoleh dari kombinasi penggunaan faktor-faktor produksi di daerah penelitian. Berdasarkan hasil estimasi ini juga menunjukkan bahwa terdapat peluang hanya sebesar $2 \%$ bagi petani untuk dapat meningkatkan produksi usahataninya agar mencapai tingkat efisien teknis. Berdasarkan hasil estimasi rata-rata petani responden memiliki tingkat efisiensi teknis masih rendah yaitu sebesar 0,92 yang berarti rata-rata petani baru mencapai produksi $92 \%$ dari potensial produksi bawang dan masih terdapat $8 \%$ yang perlu dicapai petani untuk meningkatkan produksinya agar dapat mencapai efisien atau mencapai tingkat produksi potensial. Secara grafis tingkat efisiensi teknis untuk masing-masing responden dapat dilihat pada Gambar 1.

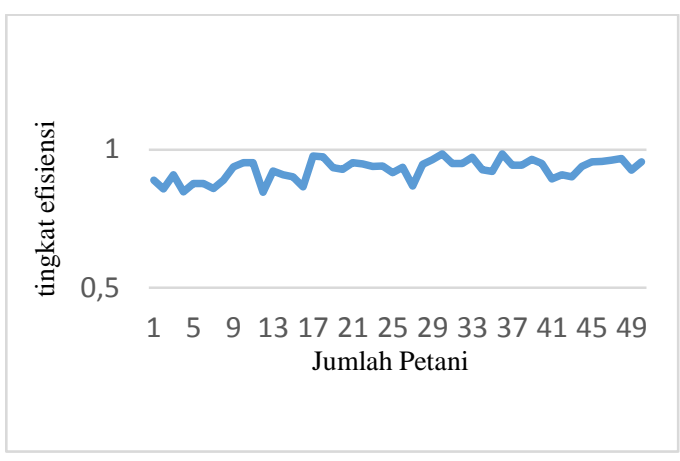

Gambar 1. Sebaran Tingkat Efisiensi Teknis Setiap Petani Responden

Gambar 1. menunjukkan tingkat efisiensi teknis ratarata sudah mencapai 94\%, artinya masih ada kesempatan sebesar $6 \%$ bagi petani untuk mencapai efisiensi produksi, ini menunjukkan kemampuan petani dalam mengelola usahataninya belum mencapai tingkat produksi secara potensial. Untuk meningkatkan efisiensi produksi bawang local Eban perlu meningkatkan kemampuannya dalam mengkombinasikan faktor-faktor produksi yang ada melalui pelatihan, penyuluhan dan adopsi inovasi baru yang lebih baik.

\section{Tingkat Efisiensi Alokatif Usahatani Bawang Lokal Eban}

Analisis Efisiensi alokatif penggunaan faktor produksi pada usahatani bawang local Eban di lokasi penelitian dapat diketahui dengan menghitung rasio NPM suatu faktor produksi dengan harga masing-masing faktor produksi Px. Untuk Efisiensi alokatif tidak semua faktor-faktor produksi dianalisis, hanyalah faktor produksi yang berpengaruh nyata terhadap produksi 
bawang local Eban. Dalam analisis faktor-faktor yang mempengaruhi produksi bawang lokal Eban di lokasi penelitian dengan menggunakan pendekatan stochastic frontier dan menggunakan metode MLE (Maximum Likelihood Estimation) didapat bahwa faktor produksi yang berpengaruh secara nyata terhadap produksi bawang local Eban yaitu faktor pupuk kandang, sehingga hanya faktor produksi tersebut yang dihitung efisiensi alokatifnya.

\section{Efisiensi Alokatif Penggunaan Luas Lahan.}

Berdasarkan data hasil analisis. diketahui NPMx/Px penggunaan pupuk kandang sebesar 1.58 dimana angka ini lebih besar dari 1, sehingga penggunaan pupuk kandang di lokasi penelitian secara alokatif tidak efisien. Belum efisiennya penggunaan pupuk kandang secara alokatif disebabkan selain oleh kemampuan petani dalam mengelola usahataninya, juga disebabkan oleh petani tidak membeli pupuk kandang. Dengan demikian secara alokatif penggunaan pupuk kandang dapat dikatakan tidak efisien, karena menurut Soekartawi (2002) seseorang dikatakan mencapai efisiensi secara alokatif jika memperoleh keuntungan dari usaha yang didilakukan.

\section{Faktor-Faktor yang Mempengaruhi Inefisiensi Usahatani bawang lokal Eban}

Dalam penelitian ini, faktor-faktor yang dimasukkan dalam model yaitu umur petani, pengalaman berusahatani, pendidikan formal, pendidikan nonformal jumlah tanggungan keluarga. Hasil analisis efek inefisiensi dapat dilihat pada Tabel 3.

Tabel 3. Hasil Pendugaan Faktor-Faktor yang Mempengaruhi Inefisiensi Usahatani bawang lokal Eban di Miomaffo Barat Tahun 2017.

\begin{tabular}{lccc}
\hline & coefisien & Standar error & t-ratio \\
\hline Intersep & 6,62 & 1,25 & 4,34 \\
Umur & $-0,17$ & 0,54 & $-0,56$ \\
Pengalaman & 0,16 & 0,31 & 0,57 \\
$\begin{array}{l}\text { Pendidikan } \\
\text { Formal }\end{array}$ & $-0,25$ & 0,34 & $-1,08^{* * *}$ \\
$\begin{array}{l}\text { Pendidikan } \\
\text { Nonformal }\end{array}$ & 0,37 & 0,18 & $2,55^{* *}$ \\
$\begin{array}{l}\text { Tanggungan } \\
\text { Keluarga }\end{array}$ & 0,06 & 0,10 & 0,32 \\
\hline
\end{tabular}

Sumber : Data Primer Diolah 2017

\section{Keterangan:}

MLE (Maximum Likelihood Estimation) Variabel $\mathrm{t}$-tabel $=2.021$ (singnifikan pada tingkat kesalahan 5\%) $\mathrm{t}$-tabel $=0.680($ singnifikan pada tingkat kesalahan 25\%)

Faktor-faktor yang mempengaruhi inefisiensi usahatani bawang lokal Eban, meliputi:

\section{a. Umur}

Nilai koefisien pada faktor umur petani mempunyai tanda negatif dan besarnya adalah $-0,19$ dan nilai $\mathrm{t}_{\text {hitung }}-0,44$. Nilai $\mathrm{t}_{\text {hitung }}$ lebih kecil dari pada $\mathrm{t}_{\text {tabel }}$ yaitu $0,44<0,68$, dengan demikian faktor umur petani berpengaruh negatif tetapi tidak signifikan terhadap efek inefisiensi teknis dalam berusahatani bawang local Eban dengan tingkat kesalahan 25\%. Hal ini menunjukkan bahwa semakin bertambah umur petani akan terjadi penurunan efek inefisiensi atau untuk mencapai efisiensi teknis semakin menjauh. b.Pengalaman Usahatani

Hasil estimasi menunjukkan bahwa koefisien pengalaman benilai positif namun tidak berpengaruh signifikan terhadap inefisiensi teknis dengan tingkat kesalahan $25 \%$. Koefisien variabel pengalaman sebesar 0,12 dengan nilai $t_{\text {hitung }}$ lebih kecil dari nilai $\mathrm{t}_{\text {tabel }}$ yaitu sebesar $0,58<0,68$. Hal ini berarti bahwa kenaikan sebesar $25 \%$ akan meningkatkan efisiensi teknis sebesar 0,12 satuan, hasil ini tidak sesuai dengan harapan sebelumnya yaitu koefisien pengalaman bertanda negatif. Bertanda positif dan berpengaruh tidak nyatanya variabel pengalaman petani reponden karena petani selalu menggunakan dan mengikuti pola tanam serta budidaya bawang local Eban secara tradisional dan sudah turuntemurun.

b.Pendidikan Formal

Nilai koefisien pada faktor pendidikan formal petani mempunyai tanda negatif dan besarnya adalah 0,27 dan nilai $t_{\text {hitung }} 1,09$ lebih besar dari pada $t_{\text {tabel }}$ yaitu $1,09<0,68$, sehingga faktor pendidikan formal responden walaupun bertanda negatif tetapi berpengaruh nyata terhadap efek inefisiensi teknis dalam berusahatani bawang local eban dengan tingkat kesalahan $25 \%$. Pendidikan formal diukur berdasarkan jenjang pendidikan yang ditempuh petani bawang local Eban dalam menempuh masa pendidikan formalnya. Hal ini sesuai dengan harapan awal yaitu pendidikan formal berpengaruh negatif.

\section{c.Pendidikan Nonformal}

Nilai koefisien pada faktor pendidikan nonformal petani mempunyai tanda positif dan besarnya adalah 0,44 dan nilai $t_{\text {hitung }} 2,53$ lebih besar dari pada $t_{\text {tabel }}$ yaitu $2,53<2,02$, sehingga faktor pendidikan nonformal responden bertanda positif dan berpengaruh nyata terhadap efek inefisiensi teknis dalam berusahatani bawang local Eban dengan tingkat kesalahan 5\%. Pendidikan nonformal diukur berdasarkan frekuensi keikutsertaan petani dalam mengikuti pelatihan dan penyuluhah di bidang pertanian. Hal ini sesuai dengan harapan awal dari penelitian yaitu berpengaruh positif. Rata-rata petani di daerah penelitian mengikuti pendidikan nonformal sebanyak dua kali. Pendidikan nonformal berpengaruh nyata terhadap efek inefisiensi karena di dalam pendidikan nonformal petani diberikan informasi dan pemahaman tentang 
usahatani bukan pengetahuan umum seperti pada pendidikan formal.

d.Jumlah Anggota Keluarga

Nilai koefisien pada faktor jumlah anggota keluarga petani mempunyai tanda positif dan besarnya adalah 0,02 dan nilai $t_{\text {hitung }} 0,22$. Nilai $t_{\text {hitung }}$ lebih kecil dari pada $t_{\text {tabel }}$ yaitu $0,02<0,68$, sehingga faktor jumlah anggota keluarga responden berpengaruh positif tetapi tidak nyata terhadap efek inefisiensi teknis dalam berusahatani bawang local Eban dengan tingkat kesalahan 25\%. Dugaan awal dari penelitian yaitu berpengaruh negatif, akan tetapi hasil analisis menunjukkan hubungan yang positif. Hal ini menunjukkan bahwa semakin banyak jumlah anggota keluarga tidak berpengaruh terhadap tingkat efek inefisiensi. Meskipun banyaknya anggota keluarga petani, akan tetapi jika mereka kurang mengetahui cara mengelola usahatani bawang putih maka tidak akan membantu petani melakukan usahataninya.

\section{SIMPULAN}

Simpulan dari penelitian ini adalah sebagai berikut: gambaran Umum usahatani bawang putih lokal eban meliputi: Persiapan Lahan, persiapan bibit, Penanaman, Pemeliharaan, panen dan pemasaran; dan secara teknis usahatani bawang putih lokal eban sudah efisien dimana analisis yang dilakukan untuk 50 responden menunjukan rata-rata efisien yang dicapai sebesar $92 \%$, namun secara alokatif usahatani bawang putih lokal belum efisien karena hasil perhitungan NPMx/px $>1$.

\section{Pustaka}

Badan Pusat Statistik Republik Indonesia. 2009. Statistik Indonesia. Badan Pusat Statistik. Jakarta.

Badan Pusat Statistik Republik Indonesia. 2010. Statistik Indonesia. Badan Pusat Statistik. Jakarta.

Badan Pusat Statistik Republik Indonesia. 2011. Statistik Indonesia. Badan Pusat Statistik. Jakarta.

Badan Pusat Statistik Republik Indonesia. 2012. Statistik Indonesia. Badan Pusat Statistik. Jakarta.

Badan Pusat Statistik Republik Indonesia. 2013. Statistik Indonesia. Badan Pusat Statistik. Jakarta.

Badan Pusat Statistik Kabupaten Timor Tengah Utara. 2009. Timor Tengah Utara dalam Angka. Badan Pusat Statistik. Kefamenanu.

Badan Pusat Statistik Kabupaten Timor Tengah Utara. 2010. Timor Tengah Utara dalam Angka. Badan Pusat Statistik. Kefamenanu.
Badan Pusat Statistik Kabupaten Timor Tengah Utara. 2011. Timor Tengah Utara dalam Angka. Badan Pusat Statistik. Kefamenanu.

Badan Pusat Statistik Kabupaten Timor Tengah Utara. 2012. Timor Tengah Utara dalam Angka. Badan Pusat Statistik. Kefamenanu.

Badan Pusat Statistik Kabupaten Timor Tengah Utara. 2013. Timor Tengah Utara dalam Angka. Badan Pusat Statistik. Kefamenanu.

Coelli, T.J., D.S. Prasada. Rao, dan G.E. Battese. 1998. An Introduction to Efficiency and Productivity Analysis. Kluwer Academic Publishers. Boston/Dordrecht/London.

Kementerian Pertanian. 2011. Laporan Kinerja Kementerian Pertanian Republik Indonesia 2012. Kementerian Pertanian. Jakarta.

Kodde, David A dan Franz C. Palm. 1986. Wald Criteria for Jointly Testing Equality and Inequality Restriction. Econometrica, Volume 54, Issue 5, 1243-1248.

Soekartawi 2002; Teori Ekonomi Produksi, dengan pokok bahasan Fungsi Cobb Douglas. Rajawali Press. Jakarta.

Sugiyono. 2007. Metode Penelitian Kuantitatif Kualitatif. Alfabeta. Bandung. 